\title{
Erosion consequences on beach functions along the Maresme coast (NW Mediterranean, Spain)
}

\author{
Caridad Ballesteros $^{1} \cdot$ José A. Jiménez $^{1} \cdot$ Herminia I. Valdemoro $^{1} \cdot$ \\ Eva Bosom ${ }^{1}$
}

Received: 18 January 2017/Accepted: 31 August 2017/Published online: 7 September 2017

(C) The Author(s) 2017. This article is an open access publication

\begin{abstract}
A methodology to analyse the influence of erosion on beach functions at a regional scale is presented. The method considers erosion hazards at different timescales and assesses consequences by evaluating impacts on recreation and protection functions. To provide useful information to decision makers for managing these functions, hazard and consequences are integrated at the municipal level within a risk matrix. This methodology is applied at the Maresme, a 45-km sandy coast situated northward of Barcelona, which supports a strong urban and infrastructure development as well as an intensive beach recreational use. Obtained results indicate differentiated erosion implications along the region, depending on the management target considered. Thus, southern municipalities are more prone to erosion affecting the protection function of the beach and leisure use by the local population, whereas erosion will have a greater effect on foreign tourism in the northern municipalities. These results highlight the necessity to employ an articulated erosion risk assessment focusing on specific targets depending on the site in question. This methodology can help coastal managers to adopt tailored measures to manage erosion impacts towards specific goals, in a more efficient and sustainable manner.
\end{abstract}

Keywords SPRC model - Coastal erosion - Beach functions - Recreation - Protection · Risk matrix · Coastal management

Caridad Ballesteros

caridad.ballesteros@upc.edu

José A. Jiménez

jose.jimenez@upc.edu

Herminia I. Valdemoro

herminia.valdemoro@upc.edu

Eva Bosom

ebosom@gmail.com

1 Laboratori d'Enginyeria Marítima, Universitat Politècnica de Catalunya BarcelonaTech, c/Jordi

Girona 1-3, Campus Nord ed D1, 08034 Barcelona, Spain 


\section{Introduction}

Coastal zones are among the most productive yet highly threatened systems in the world (EEA 2006). Here, populations tend to be concentrated, as these zones are the most favourable for developing human activities, consequently increasing the potential effects of damage by natural and human-induced hazards. Given the combined effects of further human incursion on the coast and climate change impacts, coastal erosion and flooding are problems of increasing intensity (Marchand 2010). Hence, coastal erosion has become an important environmental concern. In the past decades, it has caused significant economic losses, ecological damage, and social problems (Roca et al. 2008a; Marchand 2010; Jiménez et al. 2012). Moreover, climate change and continuing urban sprawl will likely cause this tendency to grow (IPCC 2015). In Europe, it has been estimated that about $20,000 \mathrm{~km}$ of coastline (corresponding to $20 \%$ ) faces serious impacts of coastal erosion (EC 2005). As a result, over the last decade, the cost of coastal adaptation against flooding and erosion has been an average of 0.88 billion Euros per year (EC 2009). In the Catalan coast (NW Mediterranean), about $72 \%$ of beaches are subject to erosion, at an average retreat rate of about $1.0 \mathrm{~m}$ /year, with more than $50 \%$ of the coastal municipalities having reported damages in existing beach infrastructure (CIIRC 2010). However, beach erosion not only poses a risk to existing assets, but also causes a significant setback to recreation and tourism and, consequently, threatens one of the most important sources of the economy in coastal regions (Phillips and Jones 2006; Houston 2013).

Due to this fact, the need for including coastal hazard management within general management policies in the coastal zone is clear. Within this context, the Protocol on Integrated Coastal Zone Management in the Mediterranean (PAP/RAC 2008) explicitly includes a chapter on natural hazards where the signed parties (countries) are mentored in "preventing and mitigating the negative impact of coastal erosion more effectively, and should undertake to adopt the necessary measures to maintain or restore the natural capacity of the coast to adapt to changes, including those caused by the rise in sea levels."

Although an important amount of data on coastal erosion is currently available, there is still a gap between this information and its use by coastal managers in order to put this knowledge into practice (EC 2005). This shortfall results in major shortcomings of coastal managers, which in turn often results in deficient or uninformed decisions. Moreover, understanding coastal erosion involves an insight into all the factors that interact along the coast and an awareness of different timescales (Marchand 2010). In this context, erosion is a process that operates at a wide variety of temporal scales. Due to this fact, in order to tackle erosion, a holistic approach of processes at multiple scales is required (Fekete et al. 2009). This approach should include practical measures and principles that are also important for coastal erosion management, such as local specificity and a long-term perspective (EC 2005).

Here, we propose a methodology, framed within the Source-Pathway-Receptor-Consequence model (SPRC) that will enable the identification of the main factors inducing coastal erosion at different timescales and their associated impacts to the main beach functions in the Mediterranean coast: protection and recreation (Jiménez et al. 2011). Protection is defined as the natural function provided by the beach in safeguarding the hinterland (infrastructure and/or socio-economic receptors) from direct wave action, whereas recreation makes reference to the space provided by the beach for leisure purposes. The methodology also includes an assessment of the resulting consequences, by taking into account socio-economic indicators that determine the relative importance of each function. This information is integrated at the most adequate spatial and temporal 
management scale and is combined within a risk matrix that will permit coastal managers to make decisions for specific management targets.

Within this context, the main aim of this paper is to present a methodology to analyse erosion consequences at a regional scale, considering the implications of processes acting at different timescales affecting coastal functions. This is applied in the Maresme coast (NW Mediterranean, Spain, Fig. 1). This area has been selected because it can be considered a good example of a typical sensitive Mediterranean coastal stretch subjected to significant erosion, and where potential consequences are also significant due to the intense recreational use of existing beaches and the presence of infrastructure very close to the shoreline. Thus, it illustrates the versatility of the methodology given the spatial variability in the magnitude of the hazards and potential consequences. This area has been previously used to illustrate the increase of urban sprawl and infrastructure development in lowland landscapes in the Mediterranean region (Parcerisas et al. 2012).

The structure of the remainder of this paper is as follows: Sect. 2 describes the study case (the Maresme coast) and the data used, Sect. 3 presents the methodology with different subsections where the general framework and the indicators and concepts used in this study are presented, Sect. 4 gives results obtained for the different erosion hazard

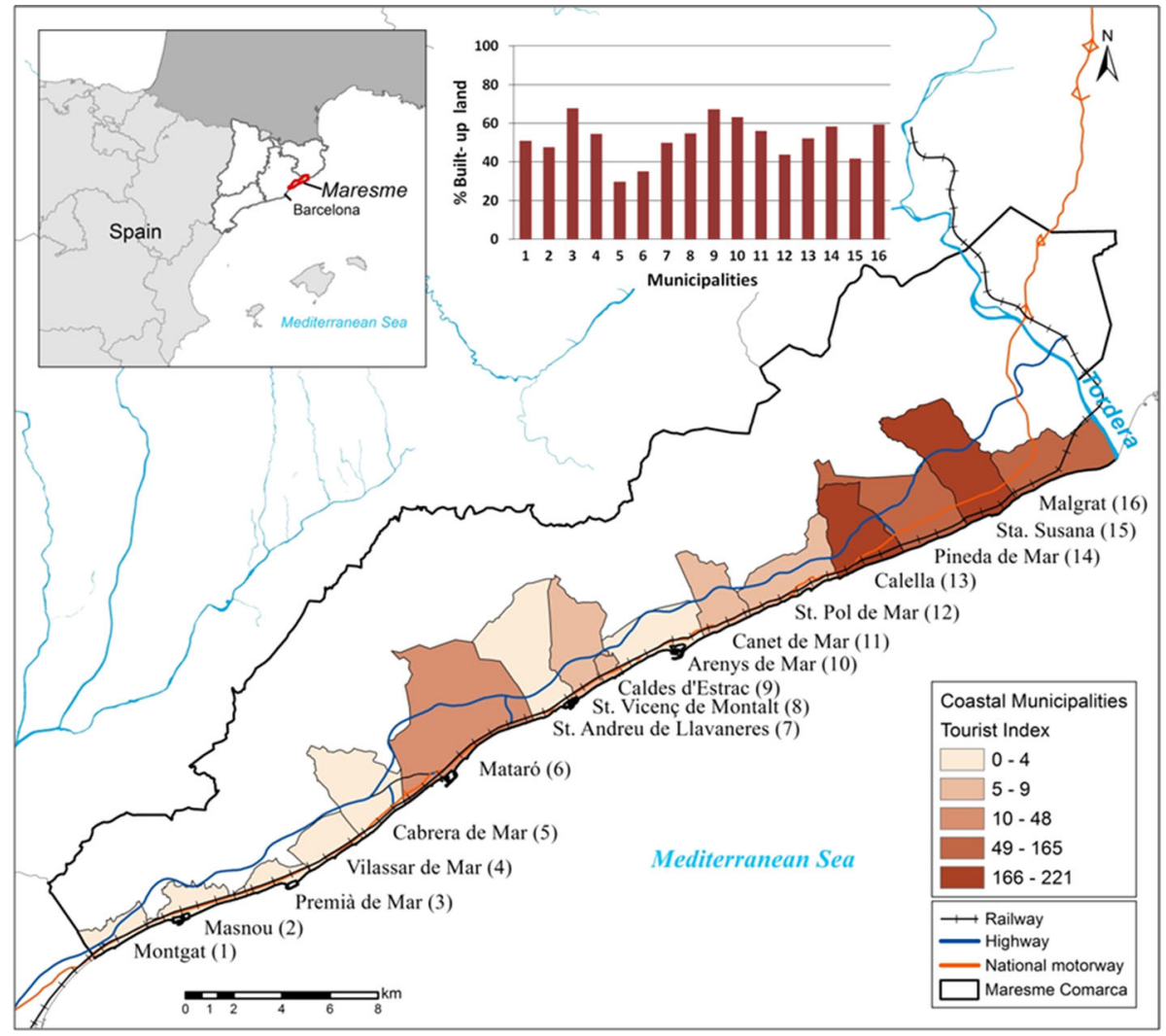

Fig. 1 Area of study (numbers along the coast are numerical codes for each municipality. Tourist index is an indicator of the economic importance of tourism for each municipality—see text for details. \% of built-up land is the percentage of urbanised land in the coastal zone for each municipality—see text for details) 
components, which are presented individually and integrally within the risk matrix. In the final two Sects. 5 and 6, the discussion and the conclusions of this work are presented, respectively.

\section{Study area and data}

\subsection{Study area}

The case study site is the Maresme, a coastal region situated $40 \mathrm{~km}$ northwards of the city of Barcelona (Fig. 1). Within the Catalan coast, where a variety of coastal environments can be found (Brenner et al. 2010), the Maresme represents a sedimentary coast comprised of straight, coarse, sandy beaches. Over several years, the decrease in river-supplied sediment and the presence of new infrastructure along the coast, such as marinas, has caused a progressive narrowing of its sandy fringe. Littoral dynamics and longshore sediment transport have induced a sedimentary behaviour in which deposits tend to be accumulated upcoast of marinas, whereas downcoast of marinas beaches is eroded and/or in some cases completely disappear. This leads to major issues for coastal managers who have dedicated concerted efforts in re-establishing the coastline. In order to illustrate the problem, about 10 million $\mathrm{m}^{3}$ of sand has been used in different beach nourishment operations in this area since 1987 (Jiménez et al. 2011). Recently, CEDEX (2014) compiled existing studies on coastline evolution in the study area to identify sectors requiring coastal actuations to counteract observed shoreline retreats.

From an administrative point of view, the Maresme coast comprises 16 municipalities, which represent the most densely populated areas of the region (IDESCAT 2014). The proximity to Barcelona and the presence of important communication routes, such as the railway and a national highway, have significantly influenced the economy of this region. Nonetheless, two separate socio-economic developments have been established along the coast: the southern municipalities near Barcelona, characterised by a metropolitan sprawl and a large network of infrastructure catering to residential development, and the northern municipalities near the most important tourist destination in Catalonia (Costa Brava), favouring tourism-lead development (see Fig. 1).

Along the Maresme coast, a strong urban infrastructure development and the presence of tourist activities, coupled with coastal erosion, have caused beach malfunctions (Jiménez et al. 2011). In the southern municipalities, a reduction in the natural protection of the beach has triggered direct wave impacts, causing damage to the railway. Here, several coastal revetments have been constructed in order to protect the infrastructure. In the northern municipalities, coastal erosion has caused problems for the local economy, which is directly dependent on tourism, such as a reduction in beach size and in the economic value of property.

\subsection{Data}

Different data have been used in this study to assess the erosion components and their consequences.

Wave data are used to characterise the episodic component of the erosion, which is done by means of an extreme distribution of storm-induced shoreline retreat. To obtain a reliable extreme distribution representative of the climatic characteristics of the study area, long 
time series of wave data are required. For this purpose, we have used one of the longest existing datasets, the hindcast SIMAR-44 database. This database was generated from the high-resolution modelling of the atmosphere, sea level, and waves developed by Puertos del Estado within the HIPOCAS project (Guedes-Soares et al. 2002; Ratsimandresy et al. 2008). Data used covered the period from January 1, 1958 to December 31, 2001, as time series of meteorological tide level, significant wave height $H_{\mathrm{m} 0}$, peak period $T_{\mathrm{p}}$, and the mean wave direction every $3 \mathrm{~h}$.

To define the medium-term erosion component, as well as the actual beach status (beach width), aerial photographs provided by the Institut Cartogràphic de Catalunya have been analysed. Shoreline data covering the period 1995-2010 have been used to characterise the medium-term component. This period can be considered as representative of the evolution of the system under current conditions since most of major perturbations (harbours, coastal engineering works, artificial nourishments) were completed before 1995. Digital terrain model (DTM) data supplied by the same institute (ICGC 2015) are used to characterise the beachface slope in the assessment of the long-term erosion component. In this case, the sea level rise (SLR) projections RCP8.5 from the IPCC AR5 (Church et al. 2013) are considered.

Finally, to evaluate the socio-economic consequences, data based on taxes generated from tourism were acquired from La Caixa Bank (2013). Other statistical data were obtained from the Institute of Statistics of Catalonia (IDESCAT). In order to define the territorial exposure values, information about urban planning and infrastructure from the Departament del Territori i Sostenibilitat (Generalitat de Catalunya 2016) was also employed.

\section{Methodology}

\subsection{General framework}

The methodological framework adopted in this work is the well-known SPRC model. This model was first used in natural science for pollutants (Holdgate 1979) and has been subsequently used for different kinds of risk analysis. Particularly, it is widely used in flood risk assessment (Gouldby and Samuels 2005; Narayan et al. 2014) and has become a wellestablished framework in coastal risk management (Sayers et al. 2002; Evans et al. 2004; Narayan et al. 2014). Here, it has been adapted to assess the impacts of beach erosion because its versatility permits a clear, synthesised representation of the chain of all the components and linkages involved, from forcing to consequences (Fig. 2).

Sources include forcings determining or conditioning the erosion process in the coast. They cover all scales and range from those acting at very large spatial and long-term scales such as the effects of SLR, to those associated with the episodic scale such as storm events (Fig. 2). These sources determine the pathway, which although known as "erosion" in generic terms; here, it is decomposed into three hazards components, each one associated with a specific timescale and characterised by a corresponding shoreline rate of displacement. In the case of the medium- and long-term components, they are calculated as a time-averaged erosion rate (m/year), whereas the episodic component is calculated as the shoreline retreat $(\mathrm{m})$ during the storm associated to a given probability of occurrence. These components are subsequently integrated in order to assess how the beach (receptor) is affected in terms of providing relevant functions for the area, i.e. recreation and 
Source

Pathway

Receptor - Consequences

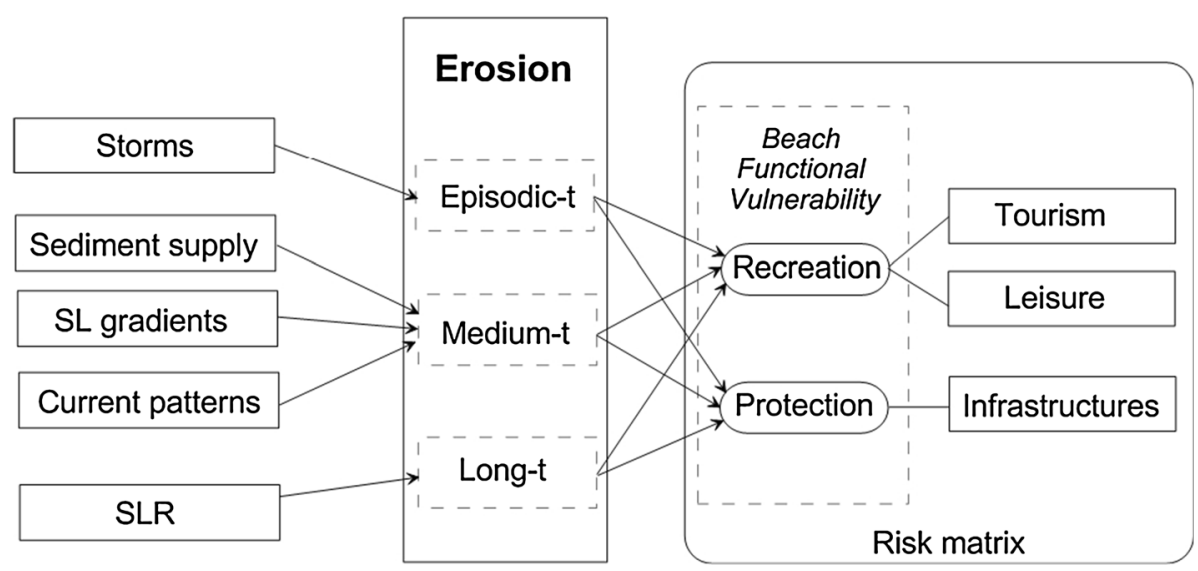

Fig. 2 SPRC model to analyse erosion consequences on beach functions

protection. In order to measure the changes in the beach state affecting a given function, we here introduce the concept of beach functional vulnerability (BFV). This is a measure of the lack of capacity of the beach to properly provide a given function and that can be affected by coastal hazards (here restricted to erosion). Finally, the practical consequences of these socio-economic changes are measured in terms of a series of indicators representing relevant aspects of the analysed functions. For recreation, two indexes have been proposed, one measuring the tourist (economic) component and one measuring the leisure (social) component. For protection, an index quantifying value at the hinterland to be protected is presented.

Consequences (through the proposed indexes) and hazards (represented by the BFV) are jointly considered to assess the effects of erosion for coastal management. To do this, we combine both components in a risk matrix, where their values are spatially integrated at the management (municipality) scale and are then compared to identify and rank the most sensitive areas along the coast.

\subsection{Erosion hazard components}

As mentioned, erosion is considered here as the "integrated" hazard of the action of three components which are the result of different processes acting at different timescales.

\subsubsection{Episodic-term}

The episodic component corresponds to the instantaneous beach erosion induced by the impact of a storm on the coast. Although the induced beach erosion takes place at a timescale of hours and days (the duration of the storm), it is considered as representative of the episodic scale due to the stochastic nature of the forcing, the storms. Due to this, the characterisation of this hazard component is undertaken in probabilistic terms, i.e. the magnitude of the hazard associated with a given probability of occurrence. To this end, we obtain the extreme probability distribution of the shoreline retreat for the study area following the approach of Bosom and Jiménez (2011). The procedure is as follows; first, 
we identify the annual maximum storms in our 44-year long wave time series. Then, we calculate the expected induced beach erosion using the bulk erosion model of Mendoza and Jiménez (2006). This model predicts the storm-induced beach erosion as a function of storm properties (wave height, period and storm duration) and beach characteristics (sediment grain size and beach slope) and is applied to selected representative profiles along the study area (as a function of their sediment and profile shape). Finally, obtained sets of erosion magnitudes are fitted by a generalised extreme value (GEV) probability distribution (one per each representative profile type). This permits to know the expected storm-induced erosion at any probability of occurrence. It should be noted that we use the annual maximum method due to the long duration of used wave time series; otherwise, the P.O.T. method to characterise storm events should be used.

\subsubsection{Medium-term}

The medium-term erosion component is associated with a timescale from years to few decades. At the study site, it is driven by alongshore gradients in longshore sediment transport rates of natural and anthropogenic origins, such as the presence of different marinas and coastal structures acting as barriers for the southwards directed net longshore sediment transport. This component has been empirically derived by analysing shoreline data to obtain representative shoreline rates of displacement. This has been done by applying a least-squares linear regression analysis of shoreline data over time. This method filters out short-term shoreline fluctuations and retains the main shoreline evolution trend (e.g. Dolan et al. 1991; Fenster et al. 1993), which is the medium-term evolution (erosion when negative) component.

This component has been evaluated through an analysis of the shoreline evolution over a period of a few decades using aerial photography from 1995 to 2010. As previously mentioned, this period can be considered as representative of the system behaviour under current conditions since most of major perturbations (harbours, coastal engineering works and artificial nourishments) were completed before 1995. The analysis has been applied to control points along the coast with a spacing of $100 \mathrm{~m}$. The timeframe of the analysis can be considered as representative of this timescale because, in areas where the littoral dynamics is strongly dominated by the longshore sediment transport, shoreline evolution rates calculated using this technique require relatively short periods to reflect the dominant trend. This is the case for the study area, where, as discussed, mid-term shoreline changes are driven by the southwards directed net longshore sediment transport rates (CIIRC 2010; CEDEX 2014). Obtained shoreline evolution rates can be used to estimate future (decadal) beach configurations provided conditions do not change (i.e. in the absence of any new coastal engineering measure).

\subsubsection{Long-term}

The long-term component of the erosion hazard is that associated with a timescale of several decades. This component is driven by processes acting at the long-term scale such as SLR, as well as by the cumulative effect (residual) of shorter-term processes such as alongshore gradients in sediment transport rates. Since the latter are directly characterised at the corresponding timescale, in this study we consider the SLR-induced erosion as the intrinsic long-term component. To evaluate this component, we assume that the SLRinduced response on sedimentary coasts can be modelled using the Bruun model (Bruun 1962). This model is based on the assumption of the existence of an equilibrium beach 
profile under current maritime climate. A change in the position of the mean sea level (MSL) will not affect the shape of the equilibrium profile which will only react to maintain its constant shape with respect to the new MSL. To do this, the model predicts a landwards and upwards movement of the beach profile, which results in a shoreline retreat. In spite of the fact that the Bruun rule is the most common way to assess SLR-induced shoreline retreat (e.g. Le Cozannet et al. 2014), there is a disagreement about its validity at the local scale. Many researchers use it to estimate an order of magnitude of the expected shoreline retreat (e.g. Nicholls and Cazenave 2010; Le Cozannet et al. 2014; Jiménez et al. 2017), whereas others claim that it should only be applied on a small number of coasts due to its simplicity and assumptions (e.g. Cooper and Pilkey 2004). In the absence of a generally accepted morphological model, we assume that the Bruun rule can be used to estimate an order of magnitude of SLR-induced shoreline retreat at the regional scale. In consequence, we apply the model to compute the expected regional long-term erosion rate along the area of study, i.e. a unique value of the shoreline retreat for the entire study area.

\subsection{Consequences}

Many approaches exist for assessing the consequences induced by coastal hazards (e.g. Cooper and McLaughlin 1998; McLaughlin et al. 2002; Boruff et al. 2005; Del Rio and Gracia 2009). However, although there are well-established approaches (e.g. Messner et al. 2007; Green et al. 2011; FEMA 2013; Penning-Rowsell et al. 2013), in many cases they depend on the type of hazard analysed and their implications for the applicable socioeconomic and natural systems. Erosion is a process that can clearly be reflected in a direct impact that results in beach retreat. However, beach functions can have indirect consequences that can go beyond the direct impact, resulting in important losses to the local economy. In this work, we address these consequences by selecting a set of socio-economic indicators related to the function of interest. In this sense, indicators have been developed and selected to characterise the importance of the analysed functions (protection and recreation) and they should also be representative at the basic management scale, that is, at the municipality level.

Focusing on the recreational function of the coast, two differentiated typologies can be distinguished: (a) beaches with a tourist focus, representing one of the most important sources of income for the local economy, and (b) a recreational use of beaches by the local population.

In order to obtain a representative value of the importance of coastal tourism, a direct economic value of the beaches should be considered (Ariza et al. 2012; Houston 2013). However, this evaluation requires a thorough analysis of the many factors which should be considered in order to obtain reliable information. In the absence of this direct economic value, a representative indicator of tourism at municipality level is used here. The tourist index developed by La Caixa Bank (2013), is a relative index based on tax revenues (Business Activities Tax), which takes into account the number of rooms, the annual occupancy rate, and the category of tourist establishments (budget hotel, campground, etc.). The index value is the percentage share of each municipality relative to the entire nation, i.e.:

$$
\text { Tourist index }=\frac{\text { Municipality tax rate }}{\text { Total taxes rates in Spain }} \times 100,000
$$


In order to carry out a regional assessment, the absolute tourist index value has been normalised for the study area obtaining a value for each municipality from 0 to 1 .

It should be indicated that although this index represents a value for the entire municipality, in the study area as in most of coastal Mediterranean regions, tourism based on coastal activities is the major contributor.

In order to consider the role played by the local population in the recreational use of the coast, an indicator which expresses the user density of locals "served" by the beaches has been developed. Here, it is assumed that the potential beach use will be proportional to the total municipality population, and therefore, it can be said that the higher the population, the larger the beach use demand. The index is expressed as follows:

$$
\text { Leisure index }=\frac{\text { Total municipality population }}{\text { Length of municipality coastline }(\mathrm{m})}
$$

As presented for the tourist index, the leisure index is normalised at regional scale obtaining a value for each municipality from 0 to 1 .

Regarding the protection function of the beach, an index to quantify the main infrastructures at the coast has been developed. The rationale behind this is that this function will be especially relevant in those places with elements susceptible to be protected. To do this, and taking into account the characteristics of the study site, three components have been considered within a buffer area: built-up urban areas, roads, and the railway. In order to obtain a value at the municipality level, these three components have been normalised with respect to the total buffer area (built-up areas) and to the coastline length (roads and railway).

To define the buffer area, the hazard reach should be considered. In this case, with a focus on erosion and the characteristics of the study area, damages in the hinterland occur in a narrow fringe along the shoreline just behind the beach, and therefore, a buffer area of $100 \mathrm{~m}$ inland is considered.

To aggregate the three components measured in the index, it is considered that damages reported for each component (roads, railway, and built-up areas) can be similar in consequence, and so an additive aggregation method, assuming a linear relationship, is taken into account as expressed in Eq. 3;

$$
\text { Infrastructure index }=\frac{\frac{\operatorname{Urban} \text { surface }\left(\mathrm{km}^{2}\right)}{\text { Buffer area }\left(\mathrm{km}^{2}\right)}+\frac{\text { Roads }(\mathrm{km})}{\text { Coastline }(\mathrm{km})}+\frac{\text { Railway }(\mathrm{km})}{\text { Coastline }(\mathrm{km})}}{3}
$$

Thus, a value from 0 to 1 will be obtained for each municipality. Although the information stated by this index does not specially represent the direct damages, this index characterises the coast in terms of the number of infrastructure exposed and potentially damaged if the natural protection function of the coast fails.

It should be pointed out that in the analysis of the consequences, time variation is not considered given the uncertainty associated with socio-economic scenarios. In contrast to the erosion hazard components, they are taken as steady during the time frame of the analysis. However, in order to replicate the methodology presented here in other regions, if further data is available, future projections in socio-economic indicators including infrastructure development can be easily implemented in the analysis. 


\subsection{Beach functional vulnerability (BFV) and spatial integration}

As the main objective of this work is to assess the influence of erosion on beach functions, we have to characterise which is the necessary beach configuration to ensure these functions. Therefore, in order to classify the hazard in terms of its impacts, an optimum and a failure state have been established for each function (protection and recreation). The optimum state corresponds to a beach configuration which is fully able to support/provide the function of interest, whereas the failure state is given by a beach configuration which is unable to provide such a function.

For a recreational beach configuration, these limits will be fixed depending on how the space is used and the density of use for the analysed beach (Jiménez et al. 2011). These limits are site specific and have to be locally defined. According to studies on user perception and characteristics of the study area (Yepes 1999; Valdemoro and Jiménez 2006; Roca et al. 2008b; Sardá et al. 2009), it can be assumed that the optimum beach width is 35 metres. Assuming a steady affluence of users, the failure state of the beach is selected when the beach width is one-third of the optimum width, which results in an excessive density of beach users and, in consequence, in a poor recreational capacity. If applying this concept at other locations, these should be readjusted taking into account local beach use characteristics which can vary significantly (e.g. see Rodella et al. 2017 for typical beach usage in Italian beaches).

Beach configuration for the protection function is determined by the beach width required to dissipate the energy of a storm for a given probability of occurrence (Bosom and Jiménez 2011; Jiménez et al. 2011). This is equivalent to a beach wider than the storminduced erosion associated with such probability. In order to select the probability of interest, coastal managers have to define a safety level of analysis which depends on the characteristics and values of the hinterland. In this case, a beach wider than the erosion induced by a storm with a 50 years return period is considered the most appropriate for the study area (see e.g. Bosom and Jiménez 2011). Therefore, in order to define the optimum beach width, we considered the 50-yr return period storm-induced shoreline retreat plus an additional safety buffer. This buffer represents the minimum beach width required to safely maintain beach operations after the storm, in order to carry out reconstruction activities and to avoid the full exposure of the hinterland to direct wave action (Jiménez et al. 2011), and is considered to be six metres. The failure state is fixed by the beach width determined by the storm reach associated with the impact of a frequent storm, which here is defined as the 10 years return period. In any case, these limits can be modified taking into account the importance of the values at exposure along the coast of interest, as well as the safety level fixed by local stakeholders.

Hence, in order to assess the influence of coastal erosion on a given function, the actual and the future status of the beach induced by the medium and the long-term erosion components is evaluated with respect to the optimum beach status required for the function of interest. To this end, the future status of the beach has been calculated according to two possible scenarios by 2035 , considering this future projection suitable to provide useful information to decision makers while maintaining the analysis within reasonable uncertainty bounds. Therefore, one scenario has been defined by the 25 years projection of the beach width using evolution rates given by the medium-term component. The second scenario corresponds to the same beach width projection plus the shoreline retreat induced by the long-term component (SLR). 
To measure the ability of the beach to provide a given function, we define an indicator, the beach functional vulnerability, BFV, which is computed taking into account the beach status at a given time $(\beta)$ as a function of the optimum and failure states (see Table 1). It varies between 0 (representing a beach status able to properly provide the selected function) and 1 (a beach without any capacity to provide the target function). This indicator is calculated every $100 \mathrm{~m}$ along the study area to characterise local beaches.

With this approach, the erosion hazard is characterised not only by the physical consequences, i.e. induced shoreline retreat, but also by the practical (end-user oriented) consequences, i.e. capacity to provide a given function.

In order to provide a management-oriented value at regional scale, BFV values locally obtained (every $100 \mathrm{~m}$ along the coast) are spatially aggregated at the municipality scale, which represents the smallest administrative level in Spain. Because the main objective of the management is to reduce/mitigate erosion consequences, a weighted averaging to characterise the aggregate impact at municipality scale has been adopted (Table 2). The underlying hypothesis is that eroding beaches, which will result in an exposition of existing infrastructure and/or decreasing carrying capacity of the beach, will not be compensated by wider beaches in areas already well protected or wide enough to support recreation. This replicates the observed preference of users to concentrate in a narrow fringe close to the shoreline, even in very wide beaches. A decreasing linearly weighting scale (Table 2) has been selected to give more importance to those stretches with larger BFV values (narrowing beaches) than stretches with lower BFV values corresponding to stable or wide beaches. This method highlights stretches at risk in order to obtain a final value at the municipality level.

Thus, the integrated beach functional vulnerability $\left(\mathrm{BFV}^{\prime}\right)$ at the scale of interest is given by

$$
\mathrm{BFV}^{\prime}=\sum_{i=1, n} \alpha_{i} \mathrm{BFV}_{i} l_{i} / \sum_{\text {total }} l_{i}
$$

where BFV represents the beach functional vulnerability of a given stretch, $\alpha_{i}$ the corresponding weights and $l_{i}$ the length of the coastal stretch.

\section{Results}

\subsection{Erosion hazard components}

The following is a presentation of the obtained results for erosion hazards at each timescale.

\subsubsection{Episodic-term}

As was mentioned before, this hazard component is represented by the storm-induced shoreline erosion. This is represented here by an extreme probability distribution of the shoreline erosion which has been computed for the different beaches along the study area. Figure 3 shows the obtained extreme erosion climates for all beach types along the Maresme coast (dashed lines) in function of their sediment size and beach profile together with the representative erosion climate (solid line), provided by the weighted average of the individual beaches taking into account their relative contribution to the total coastline. 


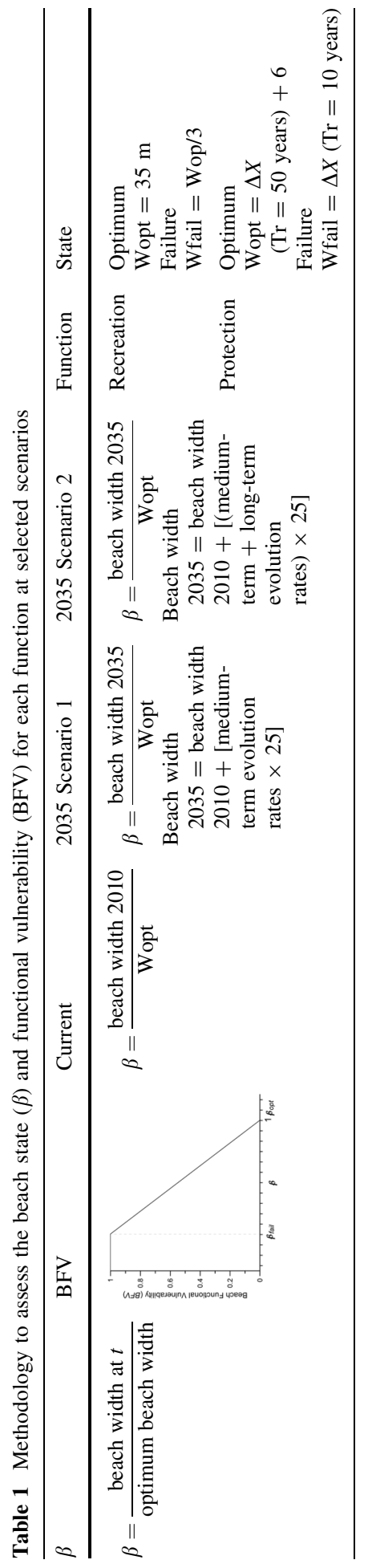


Table 2 Weights assigned

\begin{tabular}{ll}
\hline Intervals (BFV) & Weights $(\alpha)$ \\
\hline$[0.0-0.2]$ & 0.125 \\
{$[0.2-0.4]$} & 0.25 \\
{$[0.4-0.6]$} & 0.50 \\
{$[0.6-0.8]$} & 0.75 \\
{$[0.8-1.0]$} & 1 \\
\hline
\end{tabular}

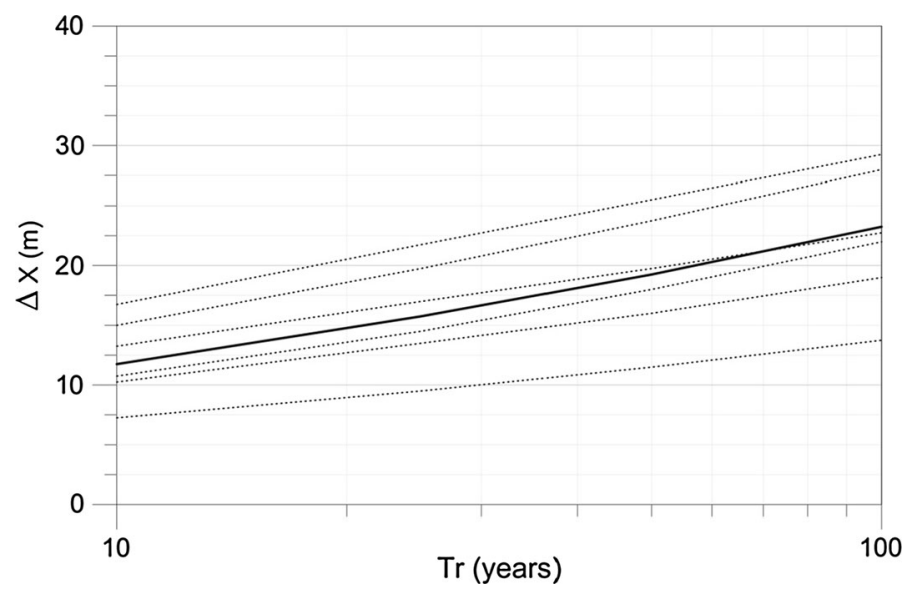

Fig. 3 Representative extreme probability distribution of storm-induced shoreline erosion in the Maresme coast (dashed lines show range of computed shoreline retreat probability distribution for different beaches along the coast, and the solid thick line is the representative-spatially averaged-one)

As can be seen, although we can assume that incident wave climate is uniform along the coast, there will be differences in erosion due to variations in beach morphology.

According to the obtained probability distribution, the average storm-induced shoreline retreat along the Maresme coast associated with a return period of 50 years is approximately $20 \mathrm{~m}$.

\subsubsection{Medium-term}

Figure 4 shows the obtained medium-term shoreline displacement rate every $100 \mathrm{~m}$ along the Maresme coast. As can be seen, there is a clear spatial pattern showing the importance of longshore sediment transport gradients in driving the observed changes. In general, the coast presents a generalised retreat with the exception of areas just upcoast of existing barriers (harbours) where accretion is observed. Moreover, the stretches just downcoast of these barriers are the areas with the largest recession rates. Overall, for the 1995-2010 period, the average evolution rate is $-0.97 \mathrm{~m} /$ year with a maximum retreat of $7.97 \mathrm{~m} / \mathrm{year}$, which was obtained at the municipality of Malgrat de Mar. 


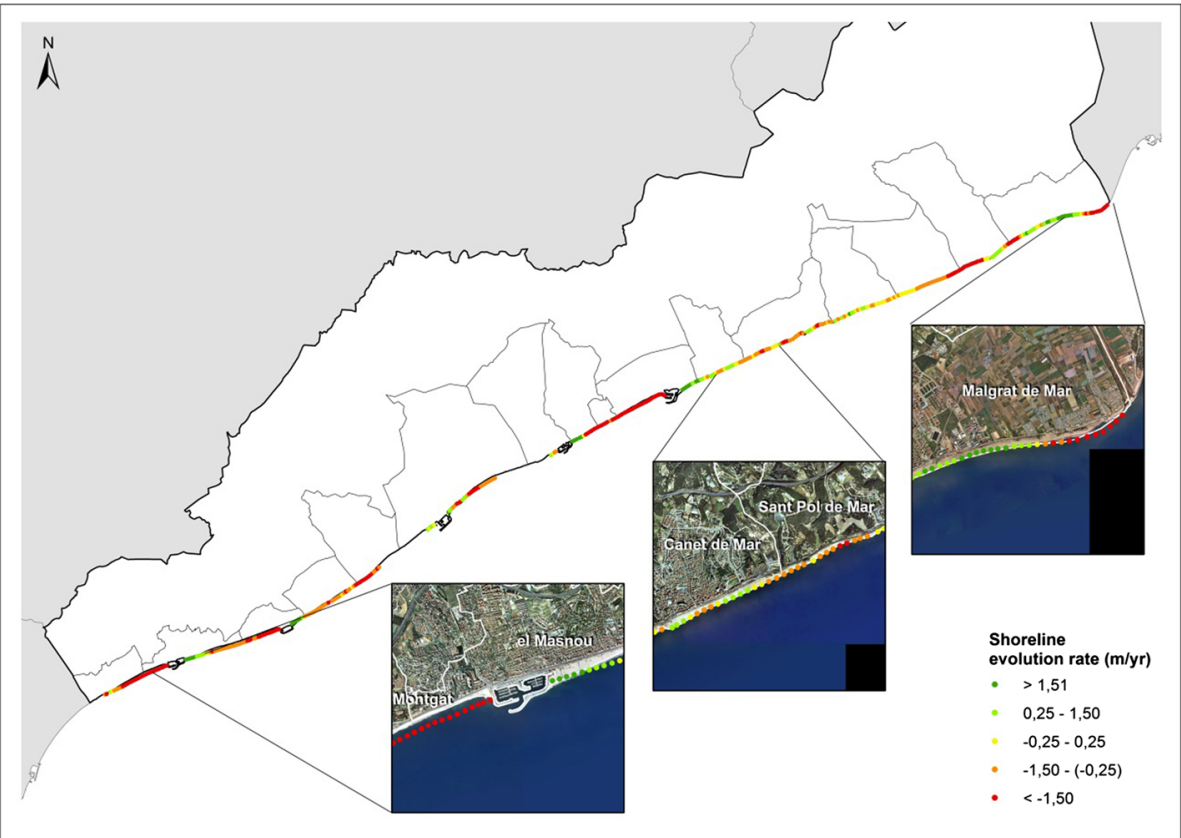

Fig. 4 Shoreline medium-term evolution rate (1995-2010)

\subsubsection{Long-term}

The long-term component is given by the computed SLR-induced shoreline retreat for the RCP8.5 scenario up to the year 2100. This component is calculated for the entire region since the morphology of the active shoreface, applying the Brunn equilibrium model, is homogeneous (similar grain size and shoreface slope). Obtained values indicate a background erosion of about $0.57 \mathrm{~m} /$ year, with an increase in erosion rates by the year 2050 due

Fig. 5 SLR-induced shoreline retreat in the Maresme

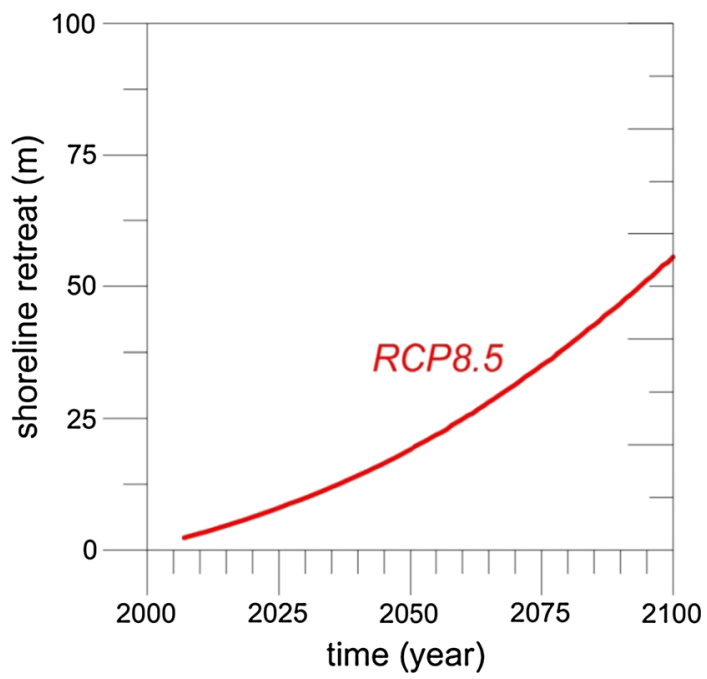


to the acceleration of SLR (Fig. 5). Expected shoreline retreats are 16 and $52 \mathrm{~m}$ by 2050 and 2100, respectively, with respect to the 2010 shoreline (see Jiménez et al. 2017).

\subsection{Erosion risk matrix}

Finally, the computed erosion components (hazard) have been integrated to obtain the erosion risk matrix. As discussed, this is done for each analysed function in terms of the beach functional vulnerability, $\mathrm{BFV}^{\prime}$. The analysis for the recreational function only considers the medium and long-term components. This consideration is made because in the region, storms take place in autumn and winter, while the beach is only used for recreation in summer (Valdemoro and Jiménez 2006). Thus, beaches are generally able to recover from seasonal storm action during normal climatic years.

Figure 6 presents the obtained results for recreational use of the beaches in the area by considering a tourist (economic) and a local (leisure) use. In both cases, although the hazard is the same (same $\mathrm{BFV}^{\prime}$ considering the recreational function), the resultant risk is different as the consequences are measured taking into account different recreational interests. For a tourist use, it can be observed that at present, municipalities with a high tourist use (i.e. 13, 14, 15, 16) are subjected to low hazard values, whereas the rest of the municipalities present hazards of different magnitudes (from low to medium). In spite of these relative good current conditions, the projection by 2035 indicates an increased risk due to background erosion rates, which are mainly controlled by medium-term erosion (associated with gradients in the longshore sediment transport) rather than SLR-induced rates. By considering a local use of the beach, a different municipality risk distribution is observed: municipalities such as Matarò (6), which has the highest population within the region, and Sant Andreu de Llavaneres (7), which has the shortest coastline, present the largest risk.

Figure 7 presents the risk matrix considering the protection function of the beach. In this case, this function will be determined by the impact of storms that usually occur in winter when there is no a recreational use (Valdemoro and Jiménez 2006). Thus, here, all the erosion components are considered in the analysis. Due to this, although background erosion rates for all municipalities, controlled by the medium-term erosion, are the same as before, their associated $\mathrm{BFV}^{\prime}$ are different since the optimum and the failure beach function states will be fixed considering the episodic-term erosion component.

In Fig. 7, obtained results indicate that at the present time, high risk values dominate mostly in southern municipalities (i.e. 2, 3, 4, 6, 7), where a large density of infrastructure and narrow beaches exist in contrast to northern municipalities where there are wider beaches and a lower density of infrastructure (i.e. 13, 14, 15, 16). Here, it can be also observed that, as presented previously, by 2035 background erosion rates will substantially increase the level of associated risk in comparison with the SLR-induced rate.

\section{Discussion}

Sandy beaches provide humans with important ecosystem services, with protection and recreation usually being the most valued of these (e.g. Barbier et al. 2011) and, in consequence, become main targets in beach management plans, especially in developed coastlines (e.g. Williams and Micallef 2009). In the Catalan coast, Ariza et al. (2008) identified the dominance of recreationally oriented beach management where the beach is 

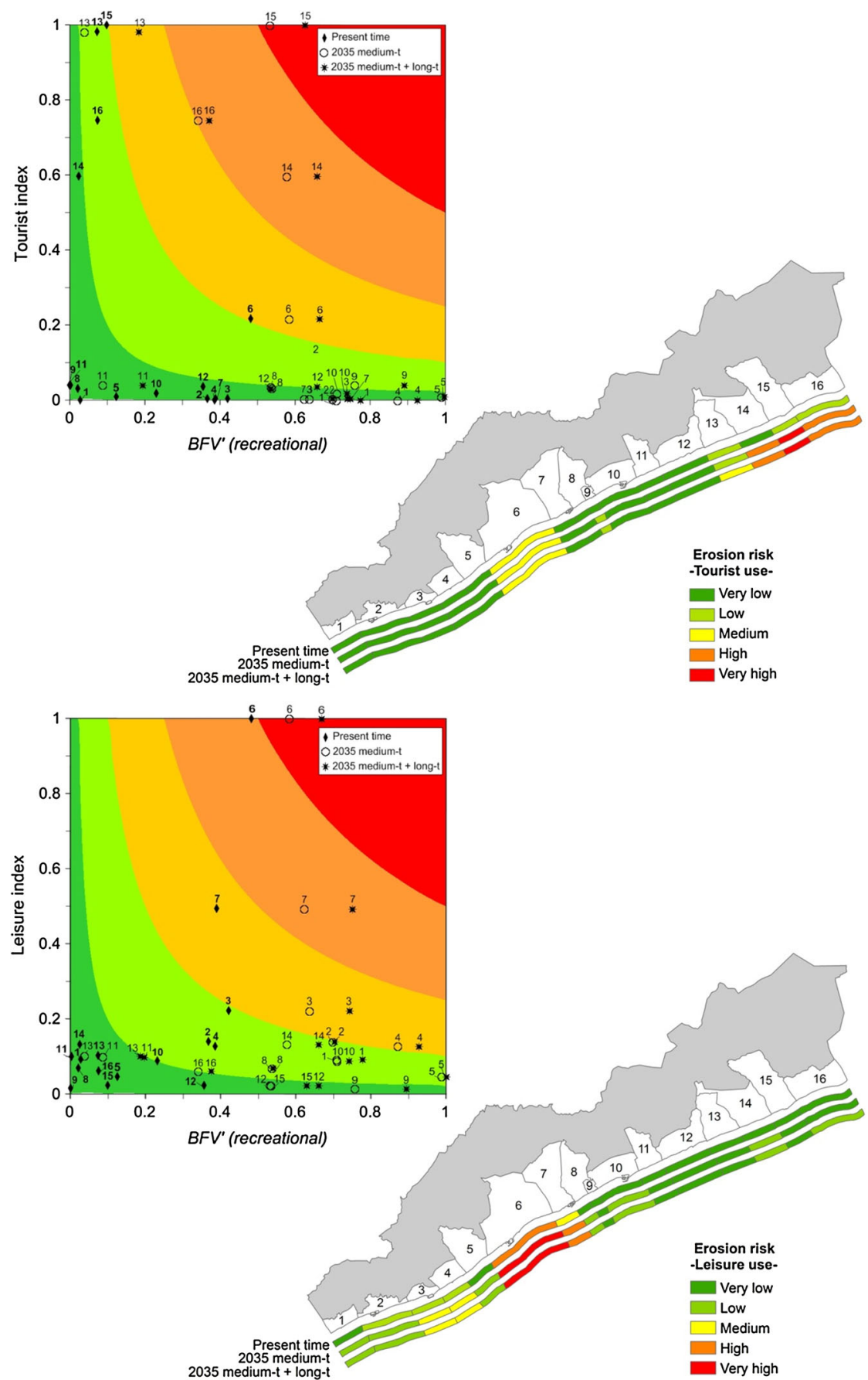

Fig. 6 Erosion risk matrix and spatial distribution in the Maresme coast for recreational beach function at current (2010) and future (2035) conditions: tourist use (top), local use (bottom) 


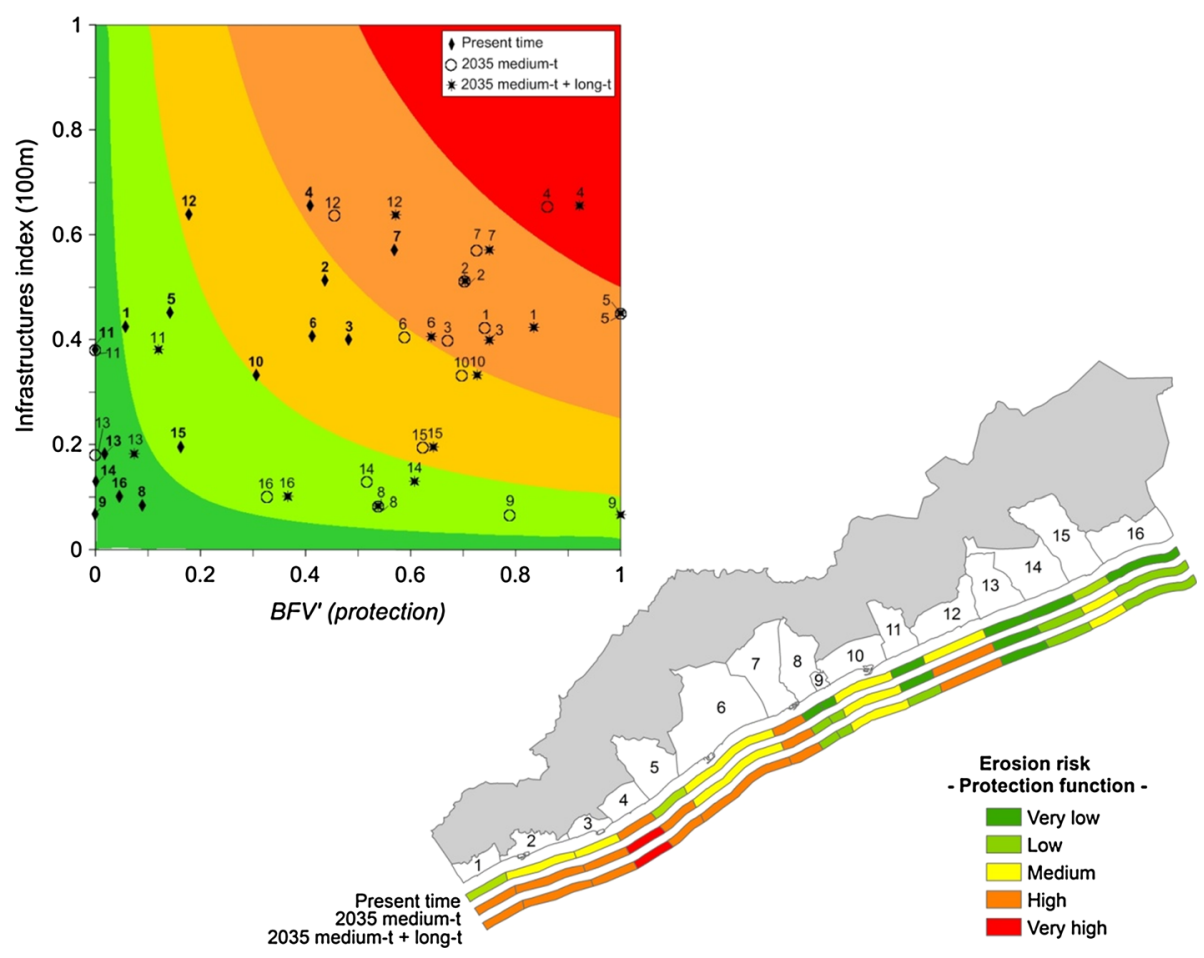

Fig. 7 Erosion risk matrix and spatial distribution in the Maresme coast considered for the protection function at current (2010) and future (2035) conditions

mainly considered as a product to be offered to users. They also found that about $50 \%$ of the municipalities had suffered erosion-related problems affecting existing beach infrastructures. Within this context, any significant variation in the beach surface may significantly affect beach use and exploitation (Valdemoro and Jiménez 2006; Jiménez et al. 2011) and it is a common feature in most of the Mediterranean coastline (e.g. Semeoshenkova and Newton 2015; Alexandrakis et al. 2015; Foteinis and Synolakis 2015; Rodella et al. 2017).

The methodology proposed here addresses this issue by identifying sensitive coastal stretches where beach erosion may influence present and future use. In order to help managers to have a regional perspective, although the analysis is undertaken at a relatively small scale (medium-term shoreline evolution rates are analysed at control points with a $100 \mathrm{~m}$ spacing), they are integrated at the municipality scale which is the minimum administrative level in Spain. This will permit to compare between units to make informed decisions on resources allocation for erosion management. Also, it will permit municipalities to assess their present and future state regarding recreation and protection issues along their coast. This is a very important issue in Spain, because although municipalities have competences in recreation management, they do not possess any such competences when it comes to beach protection (see e.g. Ariza 2011). Thus, the proper and timely prediction of the appearance of future problems will permit municipalities to approach competent administrations to obtain appropriate beach erosion management. 
It should be noted that the scale of aggregation has been selected according to the administration structure in Spain, but since the information is provided every $100 \mathrm{~m}$, the integration can be carried out at any spatial scale. Moreover, as the objective here is focused on the identification of "negative" situations (stretches at greater risk), the method of aggregation in which the hazards were integrated at this scale placed higher importance on eroded areas than on accretive ones, in order to avoid simple averaging which could mask the existence of sensitive areas.

Any hazard (erosion in this case) can be split into different components in relation to different processes and associated timescales. This disaggregation has to be done previously in accordance with the target of analysis. Therefore, it will depend on the objective whether one component must be included or not. Here, we have undertaken the analysis for recreation and protection. Since recreation is a seasonal activity that takes place in summer, and, for mid-latitudes, storms are unlikely to happen during this season, erosion components affecting recreation use are limited to medium and long-term components. In any case, if the objective of the analysis is to assess the potential impact of out-of-season storms, the episodic component could also be added. On the other hand, for the protection function, all the erosion components are included.

Practical implications of erosion on beach management have been parameterised using what we call here the beach functional vulnerability (BFV) which characterises the beach status in terms of an optimum and a failure configuration. Values characterising these configurations have to (or can) be defined in terms of local conditions which allows a flexible approach to regional beach management.

With respect to time integration, the analysis has been done for current conditions plus a minimum time for projection. The proper transfer of useful information to decision makers must permit action to be taken in order to prevent/mitigate expected damages. This requires time, and territorial planning requires in the order of a few decades. We recommend, therefore, making projections at 10-20 years in order to properly include erosion risk within management plans.

To characterise the socio-economic consequences of the hazards (erosion), selected indicators of the analysed functions have been selected here instead of classical approaches in which a distinction is made between direct versus indirect and tangible versus intangible damages (Messner et al. 2007). Indicators which are used must properly reflect the importance of the function of interest, and they must be quantifiable, comparable, and robust. However, it should be noted that this approach is primarily useful for identifying critical locations while comparing sites.

We have selected two indicators for recreation: a tourist index and a leisure index. The first one evaluates coastal tourism as one of the most important economic activities, whereas the second evaluates the social service provided by beaches (leisure). These indicators allow the analysis of the effects on resources, not only for foreign tourists, but also for the local population. For protection evaluations, the selected indicator represents the main infrastructures that would be affected in the case where the protection function of the coast fails. In this sense, deciding which assets are considered will depend on the objective of what needs to be protected (see e.g. Liquete et al. 2013). The assets were selected within a buffer area of $100 \mathrm{~m}$, taking into account the maximum and the more likely reach of coastal hazards induced by the beach narrowing process, so depending on the site, the buffer should be adjusted.

It can be said that the selected indicators are robust for the site (frequently used and well-calculated) being normalised for the study area (scale from 0 to 1). However, they can be adapted or/and substituted by any other indicator reflecting similar values, as long as 
they are acceptable to decision makers. Finally, it has to be stressed that beyond damages, this analysis considers consequences as exposure values (a measure of it). In other words, it is the maximum potential damage, since vulnerability associated with physical fragility is not considered in the analysis.

Making use of the risk matrix, the combination of both factors (hazard $\mathrm{x}$ consequences) determines lines of equal risk level which are ranked in five qualitative categories. Even though the risk matrix technique can generate false assumptions (Pickering 2010), the qualitative level of risk ranked between the two factors is fixed according to a safety level in order to prevent erosion impacts and to prioritise actions in carrying out proper risk management.

The importance of considering beach functions and socio-economic values is reflected in the Maresme coast. This region represents a clear example of differences in erosion impacts, as the aims of the analysis change. For a recreation function that is under the same erosion hazard, erosion risk varies for the different municipalities, because tourism or the local uses are reflected in the assessment of the consequences. The northern municipalities in the region are more prone to suffer erosion affecting tourism, when the overall future projections of current trends are considered. When a local use of the beaches is considered, the municipality distribution clearly varies, with the greatest risk of being able to provide a local service affecting municipalities situated in the centre and in the south of the region. Focusing on a protective function, the risk of not being protected by the beach and of suffering impacts to the infrastructure located behind it is greater for municipalities situated in the south, as they are characterised by the presence of narrow beaches and an elevated number of infrastructures near the coastline.

According to the results presented for the different erosion components, in the Maresme coast, the medium-term component (due to longshore sediment transport) constitutes the greatest risk by 2035 , when compared to the influence of the long-term component (due to SLR) by 2035 , which depends on the coastal morphology. However, in the municipalities where the medium-term component is stable and/or at equilibrium, the long-term component is more relevant. Although these results stress that efforts have to be made in the medium-term, the effect of SLR cannot be ignored when long-term strategies are developed in order to negate the effects of climate change.

It should be pointed out that obtained results have permitted the identification of the most sensitive areas expected to be affected by erosion at a regional scale. This study will thus allow a more detailed analysis to be undertaken at the local scale.

\section{Conclusions}

A methodology to assess coastal erosion impacts at different timescales and at a regional scale has been developed. It has been framed within the SPRC model, where consequences are determined in accordance with coastal characteristics and management interests.

The erosion hazard is split into different components acting at different timescales and is evaluated independently. This enables the consideration of the most important components for each coastal function and to assess the expected time evolution of the risk.

In order to assess consequences, we calculate for each erosion hazard component a beach functional vulnerability (BFV) defined as the lack of capacity of the beach to cope with erosion hazards to properly provide a given function. Since the main objective of the analysis is to provide useful information for management decisions at a regional scale, 
results are integrated at the minimum administrative/management unit which, in the case of Spain, is the municipality. The results are combined within the risk matrix which is independently obtained for each management target. This permits a comparison, in a consistent manner, of the considered risk among the different management units (municipalities) of the analysed region.

The Maresme coast represents a good example of how multiple coastal functions and local characteristics can influence the final erosion risk. From a recreational standpoint, the analysis demonstrates the need to include specific indicators for tourism and leisure. These indicators permit the proper reflection of regional differences in tourism development, while the use of beaches is equally important along the region. On the other hand, obtained results demonstrate that beaches will barely provide the required level of protection for infrastructure in the southern municipalities since most of the stretches are eroded despite supporting various forms of infrastructure. These results reflect a clear distinction between two sub-regions along the Maresme coast in terms of erosion consequences, and these should be managed differently.

By considering multiple erosion components, beach functions, and socio-economic values, it is possible to manage erosion to accomplish more specific goals, in a more efficient and sustainable manner. Taking medium- and long-term (with SLR) erosion projections into account is a prerequisite for effective risk planning. This will help to shape long-term strategies in tackling the effects of climate change and will assist coastal managers in adopting tailored measures for addressing erosion risk, as well as to provide the necessary information for supporting Integrated Coastal Zone Management (ICZM).

Acknowledgements This work has been undertaken in the framework of PaiRisClima and RISC-KIT research projects, funded by the Spanish Ministry of Economy and Competitiveness (CGL2014-55387-R) and the European Union (Grant No. 603458), respectively. The first author was supported by a PhD grant from the Ministry of Economy and Competitiveness of the Government of Spain.

Open Access This article is distributed under the terms of the Creative Commons Attribution 4.0 International License (http://creativecommons.org/licenses/by/4.0/), which permits unrestricted use, distribution, and reproduction in any medium, provided you give appropriate credit to the original author(s) and the source, provide a link to the Creative Commons license, and indicate if changes were made.

\section{References}

Alexandrakis G, Manasakis C, Kampanis NA (2015) Valuating the effects of beach erosion to tourism revenue. A management perspective. Ocean Coast Manag 111:1-11. doi:10.1016/j.ocecoaman.2015. 04.001

Ariza E (2011) An analysis of beach management framework in Spain. Study case: the Catalonian coast. J Coast Conserv 15:445-455. doi:10.1007/s11852-010-0135-y

Ariza E, Jiménez JA, Sardá R (2008) A critical assessment of beach management on the Catalan coast. Ocean Coast Manag 51:141-160. doi:10.1016/j.ocecoaman.2007.02.009

Ariza E, Ballester R, Rigall-I-Torrent R, Saló A, Roca E, Villares M, Jiménez JA, Sardá R (2012) On the relationship between quality, users' perception and economic valuation in NW Mediterranean beaches. Ocean Coast Manag 63:55-66. doi:10.1016/j.ocecoaman.2012.04.002

Barbier EB, Hacker SD, Kennedy C, Koch EW, Stier AC, Silliman BR (2011) The value of estuarine and coastal ecosystem services. Ecol Monogr 81:169-193. doi:10.1890/10-1510.1

Boruff BJ, Emrich C, Cutter SL (2005) Erosion hazard vulnerability of US coastal counties. J Coast Res 21:932-942. doi:10.2112/04-0172.1

Bosom E, Jiménez JA (2011) Probabilistic coastal vulnerability assessment to storms at regional scaleapplication to Catalan beaches (NW Mediterranean). Nat Hazards Earth Sys 11:475-484. doi:10.5194/ nhess-11-475-2011 
Brenner J, Jiménez JA, Sardá R, Garola A (2010) An assessment of the non-market value of the ecosystem services provided by the Catalan coastal zone, Spain. Ocean Coast Manag 53:27-38. doi:10.1016/j. ocecoaman.2009.10.008

Bruun P (1962) Sea level rise as a cause of shore erosion. J Waterw Harbour Div 88:117-130

CEDEX (2014) Estrategia de actuación en el Maresme. Ministerio de Fomento, Madrid

Church JA, Clark PU, Cazenave A, Gregory JM, Jevrejeva S, Levermann A, Merrifield MA, Milne GA, Nerem RS, Nunn PD, Payne AJ, Pfeffer WT, Stammer D, Unnikrishnan AS (2013) Sea level change. In: Stocker TF, Qin D, Plattner G-K, Tignor M, Allen SK, Boschung J, Nauels A, Xia Y, Bex V, Midgley PM (eds) Climate change 2013: the physical science basis. Contribution of working group I to the fifth assessment report of the intergovernmental panel on climate change. Cambridge University Press, Cambridge, pp 1137-1216

CIIRC (2010) Estat de la zona costanera a Catalunya. Resum Executiu. Generalitat de Catalunya, Barcelona

Cooper JAG, McLaughlin S (1998) Contemporary multidisciplinary approaches to coastal classification and environmental risk analysis. J Coast Res 14:512-524

Cooper JAG, Pilkey OH (2004) Sea-level rise and shoreline retreat: time to abandon the Bruun Rule. Glob Planet Change 43:157-171. doi:10.1016/j.gloplacha.2004.07.001

Del Rio L, Gracia J (2009) Erosion risk assessment of active coastal cliffs in temperate environments. Geomorphology 112:82-95. doi:10.1016/j.geomorph.2009.05.009

Dolan R, Fenster MS, Holme SJ (1991) Temporal analysis of shoreline recession and accretion. J Coast Res $1: 723-744$

European Commission (EC) (2005) Living with coastal erosion in Europe e sediment and space for sustainability. Part I-major findings and policy recommendations of the EUROSION project. Office for Official Publications of the European Communities, Luxembourg

European Commission (EC) (2009) The economics of climate change adaptation in EU coastal areas Summary report

European Environmental Agency (EEA) (2006) The changing faces of Europe's coastal areas. Report No 6. Copenhagen

Evans E, Ashley R, Hall JW, Penning-Rowsell E, Sayers P, Thorne C, Watkinson A (2004) Foresight future flooding: scientific summary: volume I-future risks and their drivers. Office of Science and Technology, London

Fekete A, Damm M, Birkmann J (2009) Scales as a challenge for vulnerability assessment. Nat Hazards 55:729-747. doi:10.1007/s11069-009-9445-5

FEMA (2013) Multi-hazard loss estimation methodology flood model, HAZUS MH MR4 technical manual. http://www.fema.gov/media-library-data/20130726-1715-25045-5075/hazus_mr4_flood_tech_manual. pdf. Accessed 5 Nov 2014

Fenster MS, Dolan R, Elder JF (1993) A new method for predicting shoreline positions from historical data. J Coast Res 9:147-171

Foteinis S, Synolakis CE (2015) Beach erosion threatens Minoan beaches: a case study of coastal retreat in Crete. Shore Beach 83:53-62

Generalitat de Catalunya (2016) Bases cartogràfiques i urbanístiques del Mapa Urbanístic de Catalunya (MUC). Direcció General d'Ordenació del Territori i Urbanisme. Departament de Territori i Sostenibilitat. territori.gencat.cat. Accessed 20 Feb 2016

Gouldby B, Samuels P (2005) Language of risk, project definitions, FLOODsite project report T32-04-01, EU GOCE-CT-2004-505420. http://www.floodsite.net/html/partner_area/project_docs/FLOODsite_ Language_of_Risk_v4_0_P1.pdf

Green C, Viavattene C, Thompson P (2011) Guidance for assessing flood losses. Deliverable 6.1 FP7 EU project CONHAZ report, (September), 1-86. http://www.mdx.ac.uk/_data/assets/pdf_file/0006/ 58794/floodsWP_FINALREPORTsept11.pdf

Guedes-Soares C, Weisse R, Carretero JC, Alvarez E (2002) A 40 years hindcast of wind, sea level and waves in european waters. In: Proceedings of the 21 st international conference on offshore mechanics and arctic engineering, pp 669-675

Holdgate MW (1979) A perspective of environmental pollution. Cambridge University Press, Cambridge, UK

Houston JR (2013) The economic value of beaches-a 2013 update. Shore Beach 81:3-11

ICGC (2015) Institut Cartografic i Geològic de Catalunya. Generalitat de Catalunya. www.icc.cat. Accessed 7 Oct 2015

IDESCAT (2014) Anuari Estadístic de Catalunya. Institut d'Estadística de Catalunya. Generalitat de Catalunya. www.idescat.cat. Accessed 10 Dec 2014

IPCC (2015) Climate change 2014: synthesis report. Contribution of working group I, II and III to the fifth assessment report of the intergovernmental panel on climate change. IPCC, Geneva 
Jiménez JA, Gracia V, Valdemoro HI, Mendoza ET, Sánchez-Arcilla A (2011) Managing erosion-induced problems in NW Mediterranean urban beaches. Ocean Coast Manag 54:907-918. doi:10.1016/j. ocecoaman.2011.05.003

Jiménez JA, Sancho A, Bosom E, Valdemoro HI, Guillén J (2012) Storm-induced damages along the Catalan coast (NW Mediterranean) during the period 1958-2008. Geomorphology 143-144:24-33. doi:10.1016/j.geomorph.2011.07.034

Jiménez JA, Valdemoro HI, Bosom E, Sánchez-Arcilla A, Nicholls RJ (2017) Impacts of sea-level riseinduced erosion on the Catalan coast. Reg Environ Change 17:593-603. doi:10.1007/s10113-0161052-x

La Caixa (2013) Anuario Económico de España, Caja de Ahorros y Pensiones de Barcelona, Barcelona. www.anuarioeco.lacaixa.comunicacions.com/java/X?cgi=caixa.anuari99.util.ChangeLanguageand lang=esp. Accessed 2 Oct 2015

Le Cozannet G, Garcin M, Yates M, Idier D, Meyssignac B (2014) Approaches to evaluate the recent impacts of sea-level rise on shoreline changes. Earth Sci Rev 138:47-60. doi:10.1016/j.earscirev.2014. 08.005

Liquete C, Zulian G, Delgado I, Stips A, Maes J (2013) Assessment of coastal protection as an ecosystem service in Europe. Ecol Indic 30:205-217. doi:10.1016/j.ecolind.2013.02.013

Marchand M (2010) Concepts and science for coastal erosion management. Concise Report for Policy Makers, Deltares

McLaughlin S, McKenna J, Cooper JAG (2002) Socio-economic data in coastal vulnerability indices: constraints and opportunities. J Coast Res 497:487-497

Mendoza ET, Jiménez JA (2006) Storm-induce beach erosion potential on the Catalonian coast. J Coastal Res SI 48:81-88. www.jstor.org/stable/25737386

Messner F, Meyer V, Penning-Rowsell EC, Green C, Tunstall S, van der Veen A (2007) Evaluating flood damages: guidance and recommendations on principles and methods. FLOODsite Project Deliverable D9.1.Wallingford: FloodSite Consortium

Narayan S, Nicholls RJ, Clarke D, Hanson S, Reeve D, Horrillo-Caraballo J, le Cozannet G, Hissel F, Kowalska B, Parda R, Willems P, Ohle N, Zanuttigh B, Losada I, Ge J, Trifonova E, Penning-Rowsell E, Vanderlinden JP (2014) The SPR systems model as a conceptual foundation for rapid integrated risk appraisals: lessons from Europe. Coast Eng 87:15-31. doi:10.1016/j.coastaleng.2013.10.021

Nicholls RJ, Cazenave A (2010) Sea-level rise and its impact on coastal zones. Science 328:1517-1520. doi:10.1126/science. 1185782

Parcerisas L, Marull J, Pino J, Tello E, Coll F, Basnou C (2012) Land use changes, landscape ecology and their socioeconomic driving forces in the Spanish Mediterranean coast (El Maresme County, 1850-2005). Environ Sci Policy 23:120-132

Penning-Rowsell EC, Priest S, Parker D, Morris J, Tunstall S, Viavattene C, Chatterton J, Owen D (2013) Flood and coastal erosion risk management: a manual for economic appraisal. Routledge, London

Phillips MR, Jones AL (2006) Erosion and tourism infrastructure in the coastal zone: problems, consequences and management. Tour Manag 27:517-524. doi:10.1016/j.tourman.2005.10.019

Pickering A (2010) Risk matrices: implied accuracy and false assumptions. J Health Saf Res Pract 2:9-16

Ratsimandresy AW, Sotillo MG, Carretero Albiach JC, Álvarez Fanjul E, Hajji H (2008) A 44-year highresolution ocean and atmospheric hindcast for the Mediterranean Basin developed within the HIPOCAS Project. Coast Eng 55:827-842. doi:10.1016/j.coastaleng.2008.02.025

Roca E, Gamboa G, Tàbara JD (2008a) Assessing the multidimensionality of coastal erosion risks: public participation and multicriteria analysis in a Mediterranean coastal system. Risk Anal 28:399-412. doi:10.1111/j.1539-6924.2008.01026.x

Roca E, Riera C, Villares M, Fragell R, Junyent R (2008b) A combined assessment of beach occupancy and public perceptions of beach quality: a case study in the Costa Brava, Spain. Ocean Coast Manag 51:839-846. doi:10.1016/j.ocecoaman.2008.08.005

Rodella I, Corbau C, Simeoni U, Utizi K (2017) Assessment of the relationship between geomorphological evolution, carrying capacity and users' perception: case studies in Emilia-Romagna (Italy). Tour Manag 59:7-22. doi:10.1016/j.tourman.2016.07.009

Sardá R, Mora J, Ariza E, Avila C, Jimenez JA (2009) Decadal shifts in beach user sand availability on the Costa Brava (Northwestern Mediterranean Coast). Tour Manag 30:158-168. doi:10.1016/j.tourman. 2008.05.011

Sayers P, Hall J, Meadowcroft I (2002) Towards risk-based food hazard management in the UK. Proc Inst Civ Eng Civ Eng 150:36-42

Semeoshenkova V, Newton A (2015) Overview of erosion and beach quality issues in three Southern European countries: Portugal, Spain and Italy. Ocean Coast Manag 118:12-21. doi:10.1016/j. ocecoaman.2015.08.013 
UNEP, MAP, PAP (2008) Protocol on Integrated Coastal Zone Management in The Mediterranean. Priority Actions Programme Regional Activity Centre, Split, p 118

Valdemoro HI, Jiménez JA (2006) The influence of shoreline dynamics on the use and exploitation of mediterranean tourist beaches. Coast Manag 34:405-423. doi:10.1080/08920750600860324

Williams A, Micallef A (2009) Beach management: principles and practice. Routledge, London

Yepes V (1999) Las playas en la gestión sostenible del litoral. Cuadernos de Turismo 4:89-110 